DEVELOPING TASK-BASED SUPPLEMENTARY ENGLISH READING MATERIALS OF DESCRIPTIVE TEXT FOR SEVENTH GRADE STUDENT OF SMP AL-WASHLIYAH 8 MEDAN

AN ARTICLE

Submitted in Partial Fulfillment of the Requirements for the Degree of Sarjana Pendidikan

By:

YOSI YUNITA AMALIA SIREGAR

Registration Number: 2151121059

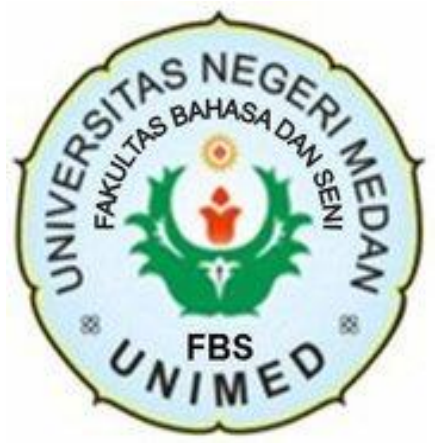

ENGLISH AND LITERATURE DEPARMENT

FACULTY OF LANGUAGES AND ARTS STATE UNIVERSITY OF MEDAN 2020 
ARTIKEL

\section{DEVELOPING TASK-BASED SUPPLEMENTARY ENGLISH READING MATERIALS OF DESCRIPTIVE TEXT FOR SEVENTH GRADE STUDENT OF SMP AL-WASHLIYAH 8 MEDAN.}

Disusun dan Diajukan oleh:

\section{Yosi Yunita Amalia Siregar} NIM. 2151121059

\section{Telah diverifikasi dan dinyatakan memenuhi syarat}

untuk diunggah pada jurnal online

Medan, Februari 2020

\section{Menyetujui}

Dosen Pembimbing I

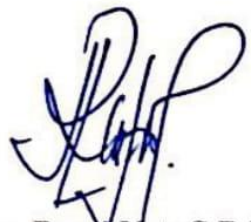

Rafika Dew Xst, S.Pd., M.Hum. NIP. 197801082005012003

\section{Dosen Pembimbing II}

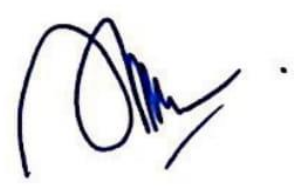

Juli Rachmadani Hsb, S.S., M.Hum. NIP. 198207112008012008

Ka. Program Studi

Pendidikan ßahasa Inkgris

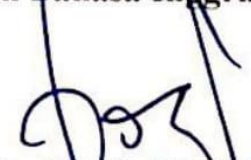

Nora Ronita Dlvi, S.Pd. S.S., M.Hum.

NIP.19800522 2008122003 


\title{
DEVELOPING TASK-BASED SUPPLEMENTARY ENGLISH READING MATERIALS OF DESCRIPTIVE TEXT FOR SEVENTH GRADE STUDENT OF SMP AL-WASHLIYAH 8 MEDAN
}

\author{
*Yosi Yunita Amalia Siregar \\ ** Rafika Dewi Nst, S.Pd., M.Hum. \\ ** Juli Rachmadani Hsb, S.S., M.Hum.
}

\begin{abstract}
Siregar, Yunita Amalia, Yosi. Registration Number: 2151121059. Developing Task-Based Supplementary English Reading Material of Descriptive Text For Seventh Grade Student of SMP Al-Washliyah 8 Medan. A Thesis.English Education Program, State University of Medan, 2019.
\end{abstract}

This study is a Research and Development (R \& D) focused on a set of task-based supplementary English reading materials of descriptive texts. The aims of this study is To develop task-based supplementary English reading materials focusing on descriptive texts for Seventh Grade Junior High School Students. The subjects were Grade Seven students of SMP Al-Washliyah 8 Medan Class VII-6. This research used quantitave research. To answer the problems of the study, the data were collected by following the research stages were conducting needs analysis, writing a course grid, designing the first draft, getting expert judgment, and revision. This research was conducted by following Masuhara (in Tomlinson, 1998) research design with several modifications. The result of this research showed that the supplementary reading materials that students need were materials which related to their real life and contain the structure and function of the texts, vocabulary and grammar lesson and interesting reading activities which allow them to interact with the teacher and other students. The product of this study was a set of task-based supplementary English reading materials focusing on descriptive texts for Grade VII students of Junior High School entitled "Reading Practice". It consisted of three units. Each unit of the developed materials consisted of 20-25 reading activities. Based on the data from the expert judgement, the mean value of all aspects of the three developed units fell into the range of $3.25 \leq x \leq 4$. It means that the developed materials were categorized as "Very Good". Thus, it can be concluded that the task-based supplementary English reading materials have been appropriate for Grade VII students of Junior High School.

Keywords: English Reading Materials, Masuhara research design, Teaching Reading 
*Graduate Status

***Lecturer Status 


\section{INTRODUCTION}

\section{A. The Background of the Study}

English is widely used in many situations, such as business, entertainment, community, social media, and education. English language as an international language makes people learn English language. The importance of learning English becomes one of the significant reason why English language is included as a lesson in the curriculum in Indonesia.Writing is commonly considered as the most difficult English skill for students to acquire to the readers. The difficulties in writing skill happen since the students have to produce the text by using English. Besides, there are many text types taught in Junior High School. The texts used are narrative, descriptive, recount, narrative, procedure and etc. Each text has different social function, generic structures, and language features.

Reading is an important skill because it functions as literacy skill. It means that when someone is going to master certain knowledge, the first thing students must does is to be able to read. By reading, someone will understand certain knowledge and he will get more knowledge. Harmer (2007) says that reading is useful for language acquisition. In line with Harmer, $\mathrm{Lu}$ (2002) states that reading is the basis of all other skills in language learning. Then, Rivers (1981) states that reading is the most important activity in any language class, not only as a source of information and a pleasurable activity, but also as the means of consolidating and extending the knowledge of the language. The syllabus of Curriculum 2013, states that one of the genres that students learned in Junior High School is description about sensory experience on how something looks, sounds, tastes. It means that the students use their imagination and knowledge in their writing.

The Ministry of Education in Indonesia designs Curriculum 2013 as the newest curriculum in Indonesia. It is stated in UU nomor 20 tahun 2013; PP nomor 19 tahun 2005 that a curriculum is a set of plans and rules about the aim, content, and course materials and also the way that is used as the orientation of teaching and learning implementation in order to reach the goal of national education. Students of junior high school should master some micro skills as stated in the Core Competence and Basic Competence.

However, what the researcher found in SMP Al-Washliyah 8 Medan Based on the observation during PPL period in Agustus - October 2018, The researcher did an interview with some teachers and students to find the specific problem. From the interview of some students they stated that they were not highly interested in reading books and texts because of the arrangement of the book is quite bored. Most of students stated that they will be interested when the book consists of some animation 
pictures that related to their daily activity based on every cartoon or animation they always watched on Television.

The researcher also found from the interview that the teacher in SMP AlWashliyah 8 Medan only used the material that are provided by the government without any addition from any resources that may help the student in learning process. Some teachers stated thet they are now too busy in teaching the students and dealing with the school administrative works. Most of the English teachers in SMP Al-Washliyah 8 Medan are also not able to design the appropriate materials since they did not get the knowledge about how to design materials in the university. When the teachers do not have the ability to do so, they tend to supplement the course book with the available materials that are sold in the market where it is quite similar with the book material provided by the government.

\section{REVIEW OF LITERATURE}

\section{A. Theoretical of framework}

This chapter provides some important terms used in this research. These terms should be elaborated and clarified in details for the readers so that both readers and writes have the same perception.

\section{Reading}

\section{a. The Nature of Reading}

The definitions of reading are important to be understood before starting to discuss reading comprehension. Reading is a very complex task and numerous definitions exist. According to Nunan (1991: 72), reading is usually conceived of as a solitary activity in which the reader interacts with the text in isolation. Then, Nunan (1989:72) adds that reading is a solitary activity which involves many interactions between readers and what they bring to the text.

\section{b. Types of Reading}

According to Brown (2004: 189-190), there are several types of reading performance as follows:

1) Perceptive

Perceptive reading task involves attending to components of larger stretches of discourse: letters, words, punctuation, and other graphemic symbols. Bottom-up processing is implied.

2) Selective In order to ascertain one's reading recognition of lexical, grammatical, or discourse feature within a very short stretch of language, certain typical 
tasks are used: picture-cued tasks, matching, true/false, multiple choice, etc. a combination of bottom-up and top-down processing may be used.

3) Interactive

Reading is a process of negotiating meaning: the reader brings to the text a set of schemata for understanding it and in take is the product of that interaction. Top-down processing is typical of such tasks, although some instances of bottom up may be necessary.

4) Extensive

Extensive reading applies to texts of more than a page, up to and including professional articles, essays, technical reports, short stories, and books. Top-down processing is assumed for most extensive tasks.

\section{Teaching Reading in Junior High School Students}

In English language teaching, reading has a special focus. Richards (2002: 273) states some reasons why reading receives a special focus. First, most of language learners often have reading as one of their most important goals because they want to be able to read for information and pleasure, for their career, and for the study progress. Second, written texts serve various pedagogical purposes. The comprehensible written texts can enhance the process of language acquisition. Good reading texts also provide good models for writing. They also provide opportunities to introduce new topics to stimulate discussion and to study language (e.g. vocabulary, grammar, and idioms). Then, reading is considered as a highly-valued skill by teachers and students.

\section{Teaching Reading in Junior High School Students}

In English language teaching, reading has a special focus. Richards (2002: 273) states some reasons why reading receives a special focus. First, most of language learners often have reading as one of their most important goals because they want to be able to read for information and pleasure, for their career, and for the study progress. Second, written texts serve various pedagogical purposes. The comprehensible written texts can enhance the process of language acquisition. Good reading texts also provide good models for writing. They also provide opportunities to introduce new topics to stimulate discussion and to study language (e.g. vocabulary, grammar, and idioms). Then, reading is considered as a highly-valued skill by teachers and students.

\section{Task-Based Language Teaching}

According to Nunan (2004), tasks become important aspects in syllabus design, classroom teaching and learner assessment. It affects educational 
policymaking in both ESL and EFL context. Task-based language teaching (TBLT) has strengthened the following principles and practices.

a. A needs-based approach is used to select the content.

b. The learners learn to communicate through interaction in the target language.

c. Authentic texts are introduced into the learning situation.

d. The learners focus not only on language but also on the learning process itself.

e. Personal experiences become important contributing elements to the classroom learning.

f. The classroom language learning and language use outside the classroom were linked.

\section{III.RESEARCH METHODOLOGY}

This study applies Research and Development (R \& D) research method that functioned to develop a new educational product based on the needs analysis. It adapted R \& D research method proposed by Borg and Gall (2014).

The research is conducting in SMP Al-Washliyah 8 Medan which is located in Jalan Sisingamangaraja No.10, Harjosari I, Medan Amplas, Kota Medan, Sumatera Utara. The subjects of this research are Grade VII-6 students in the academic year of 2019/2020. The class that became the subject of this research was Class VII D which consists of 30 students.

Collecting data, There were two questionnaires in this research namely first questionnaire and second questionnaire including conducting interviews with the teacher. The first questionnaire will use for the needs analysis. It is aim at getting the information about the learners' identity, the learners' target needs, and the learning needs. This questionnaire was in the form of multiple choice questions. The organization of the first questionnaire is presented on the table below.

The data was collected in the form of qualitative and quantitative. The qualitative data was obtained from the interview of teacher and some students. While quantitative data was obtained from the questionnaires in form of percentage. These two forms were the references of data analysis.

The questionnaires data from student changed into percentage of data, the formula like as follow: 


$$
\text { Percentages } \%=\frac{\text { Total Score }(\mathrm{n})}{\text { Maximum Score }(\mathrm{N})} \times 100 \%
$$

After that, the data transforms into qualitative data with high percentage was $100 \%$ and low percentage is $0 \%$. The next is the data described qualitatively.

\section{RESEARCH FINDINGS AND DISCUSSIONS \\ a. Research Findings}

In developing reading material, there were few steps need to be completed, namely the results of the needs analysis, the process of writing the course grid, the process of developing materials, the process of writing the materials, getting the expert judgement and revising the developed tasks, and also evaluating and revising the developed tasks based on the results of questionnaires and interviewsGathering

\section{Data and Information}

The data and information of the potential and problem were derived from the preliminary observation. The needs analysis was conducted in order to get the data from the students and their needs. It was done by distributing needs analysis questionnaire on Monday, 16 September 2019. The questionnaire was in the form of multiple choice questions. The question of the questionnaire covered the general questions about the students' profile, the students' needs, and the learning needs.

Based on the answers that the researcher got from interviewing the students, they agreed that the Material that was used by the teacher was not effective enough to master the reading skill. They also had difficulties in understanding the subject and when they were asked to answer question, they were confused how to start. Another problem that they faced was the English subject became one of the subjects that bored them the most cause the media that being used by the teacher did not give the goal of the study.

\section{Need Analysis}

In conducting this research, the second step needed to be complete was doing the needs analysis. The needs analysis was done by giving the grade eighth students questionnaire and were asked to answer some questions. This analysis of the students' needs later became the guidance to the researcher in developing supplementary English reading material 


\section{a. Questionnaire Analysis}

The questionnaire was administered to 30 grade seven students of SMP AlWashliyah 8 Medan. They were given a questionnaire which consisted of 20 questions. In order to do the needs analysis, there are three categories that need to be covered, namely necessities, lacks and wants of the learners.

\section{b. Interview Analysis}

The researcher gave an interview to the English teacher of the eighth grade of SMP Al-Washliyah 8 Medan. It was conducted to support the results of the questionnaire analysis by the students and also to get the accurate data.

\section{The Course Grid}

After the students' need and the learning needs had been identified, the next step was writing the course grid. The course grid was used as a guideline in designing the supplementary materials. There were some considerations in writing the course grid : the needs analysis, core competences, and basic competences.

Based on those considerations, the course grid consisted of unit name and title, basic competences, learning materials, learning activities, teaching kits, teacher roles, students roles, and setting. Here $i$ the explanation of some aspects of the course grid. Based on the course grid, the developed materials had three units. which were people, things and pets.

The learning objective of the lessons was to make the students understand the generic structures, social functions, and the language elements of the descriptive texts. After deciding the learning objectives the indicators were listed in detail.

\section{The Unit Design of the Materials}

After the course grid was developed, the next step was developing the materials. They are schema building, controlled practices, authentic reading practices, focused on linguistic elements, freer practices, pedagogical tasks, and reflection. The first stage up to the sixth stage is the main stages and the last stage is aimed at ending the unit. The activities in the schema building stage help the students to have schema building about the materials that are going to learn. The second stage, that is controlled practice, consists of some tasks that guide the students to learn the vocabulary related to the topic, the generic structure, and the functions of descriptive texts. The authentic reading practice stage provides reading comprehension tasks that involve the students in intensive reading practices. In the fourth stage, that is focus on linguistic elements, students learn the linguistic elements of the texts through tasks that are provided. The providing freer practices stage offers some less guided tasks. 
The sixth stage, that is introducing the pedagogical tasks stage, allows the students to relate the tasks with their real life. In the reflection, students are asked to check their progress through a task.

\section{Results of the Expert Judgment}

After being designed, the three units then became the first draft. The units had to meet the qualification of good materials from the expert judgment. In this case, expert became the second consultant. That second consultant is eligible for being an expert on material development.

The expert judgment took two consultations. In the two-consultations, there were several parts that still needed to be revised. The results of the expert judgment are presented: The grammar of the sentence is changed from simple present tense to simple past tense, The choice of context that must be changed, Add questions to students for more evaluation, The selection of images in the questions must be in accordance with the topic and title, The contrast color selection must be improved, Lots of missed-typing happens, please fix and focus, Errors in spaces and distances, please correct.

\section{CONCLUSIONS AND SUGGESTIONS}

\section{A. The conclusions}

For the reading target needs the main goal of the students in learning English is to answer all of the reaading questions correctly and be able to communicate in English well. The lack were related to the vocabulary, grammar and generic structure. The learning needs related to the students' opinion that students liked to learn the text through various activities and the materials would be interesting if consist pictures and related to students real life.

\section{B. Suggestions}

The students of SMP Al-Washliayh 8 Medan should be actively involved with their friends during reading activities. The teachers of class seventh student must be able to implement the reading material. Additional English based on assignments reading material can also be used to teach generic structure, social functions vocabulary and grammar. 


\section{REFERENCES}

Alderson, J.C. 2000. Assessing Reading. Cambridge: Cambridge University Press.

Badan Nasional Standar Pendidikan (BNSP)

Bamford, J., \& Day, R. R. (1997). Extensive reading: What is it? Why bother? Language Teacher. Kyoto-Jalt-, 21, 6-8.

Bamford, J. \& Day, R. R. 2004. Extensive Reading Activities for Teaching Language. Cambridge: Cambridge University Press.

Borg, W. R. and Gall, M.D. 1983. Educational research an introduction (4th Ed.). New York: Longman.

Brown, H. D. 1994. Principles of language learning. Third Edition, NJ: Prentice Hall.Regents. Englewood Cliffs.

Brown, H. D. 2000. Principles of language learning and teaching (4th Ed.). NewYork: Longman.

Brown, H. D. 2004. Teaching Language Assessment Principles and Classroom Practices. New York: Pearson Education, Inc.

Brown, H. D. 2007. Teaching by Principles: An Interactive Approach to Language Pedagogy. (3rd Ed.). White Plains, NY: Pearson Education.

Grabe, w., Stoller, F, L. (2011). Teaching and Researching Reading $2^{\text {nd }}$ Edition. Newyork: Routledge.

Harmer, J. 2001. The Practice of English Language Teaching. London: Longman.

Harmer, J. 2002. The Practice of English Language Teaching. London: Longman

Harmer, J. 2007. How to teach English. Essex: Pearson Longman

Hutchinson, T. \& A. Waters.1987. English for Specific Purposes. Cambridge: Cambridge University Press. 
Johnson, A. P. (2008). Teaching Reading and Writing: A Guidebook for Tutoring and Remediating Students. Estofer Road, Playmouth: Rowman \& Littlefield Education.

Klingner, J. K., Vaughn, S., \& Boardman, A. (2007). Teaching reading comprehension to students with learning difficulties. New York, NY: Guilford.

Lems, K., Miller, L. D., \& Soro, T. M. (2010). Teaching reading to English language learners: Insights from linguistics. New York: The Guilford Press.

Li, L. (2017). The Construction of English Majors' Reading Courses Group and Autonomous Learning Mode under the Network Environment. Advances in Social Science, Education and Humanities Research, 123, 916-919.

McGrath, I. 2002. Materials Evaluation and Design for Language Teaching. Edinburgh: Edinburgh University Press.

Nunan, D. 1991. Language Teaching Methodology. London: Prentice Hall.

Nunan, D. 1999. Second language teaching and learning. Boston: Heinle and Heinle Publisher.

Nunan, D. 2004. Task-based Language Teaching. Cambridge: Cambridge University Press.

Nunan, D. 1988. Language Teaching: Syllabus Design. Oxford: Oxford University Press.

Nunan, D. 1989. Designing Task for Communicative Classroom. New York: Cambridge University Press.

Reddy, R.S. 2013. Supplementary Materials to Enhance Language Skills of Learners. International Journal of Social Science \& Interdisciplinary Research, 2 (9), 143-150.

Richard, J. C. 2001. Curriculum Development in Language Teaching. Cambridge: Cambridge University Press.

Richards, J, C. and Renandya, W, A. 2002. Methodology in Language teaching: An Anthology of Current Practice. Cambridge: Cambridge University Press. 
Rivers, W M. 1981. Teaching foreign-language skills. London: The University of Chicago Press, Ltd

Smith, F. 2008. Understanding Reading. London: Lawrence Erlbaum Associates Publishers.

Spratt, M., Pulverness A. and Williams M. 2005. The teaching knowledge test course. Cambridge: Cambridge University Press.

Sugeng, Bambang. 2010. Instructional Technology, Planning Strategies for Language Education. Yogyakarta: Yogyakarta State University

Suharto, Gregorius. 2005. Penilaian hasil Belajar Bahasa Inggris. Yogyakarta: FBS UNY.

Tomlinson, B. 1998. Materials Development in Language Teaching. Cambridge: Cambridge University Press.

Tomlinson, Brian (2011). Material development in Language Teaching (2nd Ed.). Cambridge: Cambridge University Press.

Van den Branden, K. (2006). Task-Based Language Education: from A Theory to Practice. Cambridge: Cambridge University Press 